\title{
Rancang Bangun Aplikasi Simulasi Jaringan untuk Praktikum Jaringan Komputer Memanfaatkan Scapy dalam Lingkungan LXC
}

\author{
Dhimas Bagus Pramudya, Royyana Muslim Ijtihadie, dan Baskoro Adi Pratomo \\ Teknik Informatika, Fakultas Teknologi Informasi, Institut Teknologi Sepuluh Nopember (ITS) \\ Jl. Arief Rahman Hakim, Surabaya 60111 Indonesia \\ e-mail: roy@its-sby.edu
}

\begin{abstract}
Abstrak-Praktikum Jaringan Komputer yang sudah berlangsung di Jurusan Teknik Informatika dalam menyimulasikan topologi jaringan menggunakan User Mode Linux (UML). Namun server mengalami penurunan kinerja, ketika menyimulasikan topologi dalam jumlah banyak yang menggunakan host dan router. Hal tersebut mengakibatkan waktu startup yang lama, latency yang tinggi, dan kecenderungan error sering dialami server.

Linux Container merupakan lingkungan virtual berbasis container yang menyediakan ukuran image yang lebih kecil dari User Mode Linux. Proses startup pada Linux Container lebih cepat dibandingkan User Mode Linux meskipun banyak aplikasi server yang sudah dipasang. Dengan kelebihan Linux Container diatas, kecenderungan error yang diakibatkan oleh User Mode Linux dapat dikurangi. Selain itu dalam praktikum jaringan komputer manipulasi paket dengan scapy dapat dimanfaatkan untuk memperdalam praktikan dalam mengalisa paket secara detail apa saja yang dikirim dan respon yang diberikan oleh paket tersebut. Oleh karena itu dalam Tugas Akhir ini diusulkan lingkungan virtualisasi yaitu Linux Container (LXC) dan simulasi pengiriman paket menggunakan Scapy.

Dari hasil uji coba dengan sistem simulasi jaringan ini, didapatkan waktu respon untuk menangani setiap rute sekitar kurang dari satu detik sampai tujuh detik.Komputer web server yang digunakan mampu membuat virtualisasi sebanyak 400 dengan web server yang sedang diakses oleh 20 pengguna.kata.
\end{abstract}

Kata Kunci- Praktikum, Simulasi Jaringan, Linux Container, Scapy

\section{PENDAHULUAN}

$\mathrm{P}$ RAKTIKUM jaringan komputer merupakan kegiatan untuk menunjang mata kuliah jaringan komputer. Dalam praktikum jaringan komputer, praktikan diberi panduan untuk membuat simulasi dari jaringan komputer yang sebenarnya. Simulasi jaringan dalam praktikum jaringan komputer merupakan metode bagi praktikan untuk membuat topologi jaringan komputer tanpa harus memakai sumber daya yang sesungguhnya. Praktikum Jaringan Komputer yang sudah berlangsung di Jurusan Teknik Informatika dalam menyimulasikan topologi jaringan menggunakan User Mode Linux (UML). User Mode Linux merupakan aplikasi yang digunakan untuk menyimulasikan router, host dan switch dalam lingkungan virtual.

User Mode Linux mempunyai beberapa kekurangan, yaitu ketika menyimulasikan topologi dalam jumlah banyak yang menggunakan host dan router, server mengalami penurunan kinerja. Selain itu sumber daya penyimpanan di server juga berkurang karena besarnya ukuran image yang dibuat oleh UML untuk masing- masing host dan router. Hal ini dapat menyebabkan beberapa masalah seperti waktu startup yang lama, latency yang tinggi, dan kecenderungan error.

Makalah ini membahas tentang rancang bangun aplikasi simulasi jaringan untuk praktikum jaringan komputer di Teknik Informatika ITS memanfaatkan Scapy dalam lingkungan LXC. Linux Container merupakan lingkungan virtual berbasis container yang menyediakan ukuran image yang lebih kecil dari User Mode Linux [1]. Proses startup pada Linux Container lebih cepat dibandingkan User Mode Linux meskipun banyak aplikasi server yang sudah dipasang. Dengan kelebihan Linux Container diatas, kecenderungan error yang diakibatkan oleh User Mode Linux dapat dikurangi.

Scapy [2] merupakan progam untuk memanipulasi paket. Scapy dapat menata ulang sebuah paket dari beberapa protokol, mengirimkannya melalui jaringan, menganalisa paket tersebut, mencocokan antara request dan reply. Scapy juga dapat digunakan untuk scanning, tracerouting, probing, unit tests, penyerangan atau network discovery. Sehingga dalam praktikum jaringan komputer, Scapy dapat dimanfaatkan untuk memperdalam praktikan dalam mengalisa paket secara detail apa saja yang dikirim dan respon yang diberikan oleh paket tersebut.

\section{TINJAUAN PUSTAKA}

\section{A. Simulasi Jaringan}

Simulasi jaringan [3] merupakan virtual reality simulation yang digunakan untuk menirukan tabiat dari proses dan sistem jaringan sesuai dengan dunia nyata. Berbagai percobaan dapat dilakukan dengan mengubah model pada simulasi. Penggunaan simulasi dapat membantu untuk menguji hal yang terlalu beresiko jika dilakukan secara nyata.

\section{B. Linux Container $(L X C)$}

Linux Container (LXC) [4] adalah sebuah lingkungan virtualisasi dilevel sistem operasi yang dapat menjalankan sistem Linux standar yang terisolasi dalam sebuah host tanpa terpisah oleh kernel host tersebut. Tabel 1 merupakan daftar 
fitur yang diakomodasi oleh Linux Container.

Tabel 1. Daftar Fitur Linux Container

\begin{tabular}{|c|c|c|}
\hline No & Nama Fitur & Keterangan \\
\hline 1 & $\begin{array}{l}\text { Kernel } \\
\text { namespaces(inter } \\
\text { process } \\
\text { comunication, } \\
\text { mount, pid, } \\
\text { network, dan } \\
\text { user) }\end{array}$ & $\begin{array}{l}\text { Virtualisasi yang dibuat oleh Linux } \\
\text { Container memiliki lingkungan isolasi } \\
\text { sendiri berbeda dengan komputer host, } \\
\text { sehingga memiliki proses, jaringan, user, dan } \\
\text { inter process comunication yang berbeda } \\
\text { dengan komputer host. }\end{array}$ \\
\hline 2 & $\begin{array}{l}\text { Apparmor dan } \\
\text { SELinux profiles }\end{array}$ & $\begin{array}{l}\text { Fitur keamanan yang disediakan Linux } \\
\text { Container. }\end{array}$ \\
\hline 3 & Seccomp policies & $\begin{array}{l}\text { Merupakan fitur dari kernel yang dapat } \\
\text { menyaring system call yang biasa digunakan } \\
\text { oleh proses dalam sistem operasi Linux } \\
\text { beserta anak dari proses tersebut. Seccomp } \\
\text { policies dapat ditambahkan pada virtualisasi } \\
\text { oleh Linux Container. }\end{array}$ \\
\hline 4 & CGroups & $\begin{array}{l}\text { Pengguna dapat membatasi dan mengatur } \\
\text { prioritas penggunaan sumber daya seperti } \\
c p u, \text { memory, block } I / O \text {, dan network. }\end{array}$ \\
\hline
\end{tabular}

Linux Container terdiri dari beberapa komponen pengembangnya, antara lain liblxc sebagai pustaka khusus untuk Linux Container dan bahasa pemrograman yang digunakan untuk API antara lain python3, lua, go, dan ruby. Selain itu Linux Container juga menyediakan standar dalam mengontrol container-nya dan template image untuk container.

Tabel 2 merupakan daftar perintah dari Linux Container [5] yang digunakan dalam tugas akhir ini.

\section{Scapy}

Scapy [2] adalah program untuk memanipulasi sebuah paket. Scapy dapat menata ulang sebuah paket dari beberapa protokol, mengirimkannya melalui jaringan, menganalisa paket tersebut, dan mencocokan antara request dan reply.

Scapy dapat digunakan untuk scanning, tracerouting, probing, unit tests, penyerangan atau network discovery. Scapy dibangun dengan bahasa pemrograman python.

\section{Flask}

Flask [6] merupakan kerangka kerja mikro dari bahasa pemrograman python yang didukung oleh werkzeug dan jinja2. Aplikasi web yang dibuat dengan Flask disimpan dalam satu berkas .py.

Flask ingin menjadi web framework yang sederhana namun dapat diperluas dengan beragam pustaka tambahan yang sesuai dengan kebutuhan penggunanya.

\section{E. GoJS}

GoJS [7] merupakan pustaka dari Javascript untuk mengimplementasikan diagram interaktif. Diagram yang mempunyai konstruksi node dan penghubung antar node yang sulit sekalipun dapat dibuat menggunakan GoJS dengan mudah karena mempunyai template dan layout yang beragam. Selain itu, fitur yang didukung oleh GoJS antara lain drag and drop, copy and paste, data binding and models, transactional state and undo management, palettes, overviews, dan event handlers.
GoJS digunakan sebagai tampilan untuk simulasi dalam tugas akhir ini. Fitur GoJS yang dimanfaatkan dalam tugas akhir ini antara lain template, data binding and models, drag and drop, palettes dan event handlers.

Tabel 2. Daftar Perintah LXC

\begin{tabular}{|c|c|c|c|c|}
\hline No & Perintah & \multicolumn{2}{|c|}{ Contoh penggunaan } & Keterangan \\
\hline 1 & $\begin{array}{l}\text { lxc- } \\
\text { create }\end{array}$ & \multicolumn{2}{|c|}{$\begin{array}{l}\text { lxc-create }-n \text { [nama } \\
\text { kontainer] - } t \text { [nama } \\
\text { template sistem operasi] }\end{array}$} & Membuat kontainer baru. \\
\hline 2 & lxc-clone & \multicolumn{2}{|c|}{$\begin{array}{l}\text { lxc-clone -n [nama } \\
\text { kontainer baru] -o } \\
\text { [nama kontainer yang } \\
\text { ingin disalin] }\end{array}$} & $\begin{array}{l}\text { Menyalin kontainer yang } \\
\text { sudah tersedia. }\end{array}$ \\
\hline 3 & lxc-start & \multicolumn{2}{|c|}{$\begin{array}{l}\text { lxc-start }-n \text { [nama } \\
\text { kontainer] }\end{array}$} & Menghidupkan kontainer. \\
\hline 4 & lxc-stop & \multicolumn{2}{|c|}{$\begin{array}{l}\text { lxc-stop }-n \text { [nama } \\
\text { kontainer] }\end{array}$} & Mematikan kontainer. \\
\hline 5 & $\begin{array}{l}\text { lxc- } \\
\text { destroy }\end{array}$ & \multicolumn{2}{|c|}{$\begin{array}{l}\text { lxc-destroy }-n \text { [nama } \\
\text { kontainer] }\end{array}$} & Menghapus kontainer. \\
\hline 6 & lxc-ls & \multicolumn{2}{|c|}{$l x c-l s-$-fancy } & $\begin{array}{l}\text { Menampilkan semua } \\
\text { daftar kontainer yang } \\
\text { sudah dibuat dengan } \\
\text { statusnya. }\end{array}$ \\
\hline 7 & lxc-info & \multicolumn{2}{|c|}{$\begin{array}{l}\text { lxc-info -n [nama } \\
\text { kontainer] }\end{array}$} & $\begin{array}{l}\text { Menampilkan informasi } \\
\text { dari satu kontainer. }\end{array}$ \\
\hline \multicolumn{5}{|c|}{ Tabel 3. Daftar Perintah Bridge-utils } \\
\hline No & \multicolumn{2}{|l|}{ Perintah } & \multicolumn{2}{|c|}{ Keterangan } \\
\hline 1 & \multicolumn{2}{|c|}{$\begin{array}{l}\text { brctl addbr [nama } \\
\text { bridge] }\end{array}$} & \multicolumn{2}{|c|}{ Menambahkan bridge baru. } \\
\hline 2 & \multicolumn{2}{|c|}{$\begin{array}{l}\text { brctl addif [nama } \\
\text { bridge] [interface] }\end{array}$} & \multicolumn{2}{|c|}{$\begin{array}{l}\text { Menambahkan interface ethernet ke } \\
\text { dalam bridge yang sudah dibuat } \\
\text { sebelumnya. }\end{array}$} \\
\hline 3 & \multicolumn{2}{|c|}{ brctl show } & \multicolumn{2}{|c|}{$\begin{array}{l}\text { Menampilkan daftar semua bridge } \\
\text { yang sudah dibuat berserta interface } \\
\text { yang terdapat dalam bridge tersebut. }\end{array}$} \\
\hline 4 & \multicolumn{2}{|c|}{$\begin{array}{l}\text { ifconfig [nama bridge] } \\
\text { up }\end{array}$} & \multicolumn{2}{|c|}{$\begin{array}{l}\text { Menghidupkan bridge yang sudah } \\
\text { dibuat }\end{array}$} \\
\hline 5 & \multicolumn{2}{|c|}{$\begin{array}{l}\text { ifconfig [nama bridge] } \\
\text { down }\end{array}$} & \multicolumn{2}{|c|}{ Mematikan bridge yang sudah dibuat } \\
\hline 6 & \multicolumn{2}{|c|}{$\begin{array}{l}\text { ifconfig [nama bridge] } \\
\text { [alamat ip] netmask } \\
\text { [netmask] up }\end{array}$} & \multicolumn{2}{|c|}{$\begin{array}{l}\text { Menghidupkan bridge dengan } \\
\text { mengatur alamat ip dan netmask. }\end{array}$} \\
\hline
\end{tabular}

\section{F. Bridge-utils}

Bridge-utils [8] merupakan paket aplikasi yang digunakan untuk mengkonfigurasi bridge untuk ethernet di sistem operasi Linux. Bridge-utils dapat digunakan untuk menghubungkan perangkat ethernet sekaligus secara bersama-sama baik dari host yang mempunyai fisik nyata maupun berupa virtualisasi.

Dalam tugas akhir ini, Bridge-utils digunakan untuk menyimulasikan modul switch sesuai dengan keadaan di dunia nyata. Tabel 3 merupakan daftar perintah Bridge-utils.

\section{ANALISA DAN PERANCANGAN}

\section{A. Deskripsi Fitur}

Simulasi jaringan pada umumnya merupakan virtual reality simulation yang digunakan untuk menirukan tabiat dari proses dan sistem jaringan sesuai dengan dunia nyata. Secara umum, 


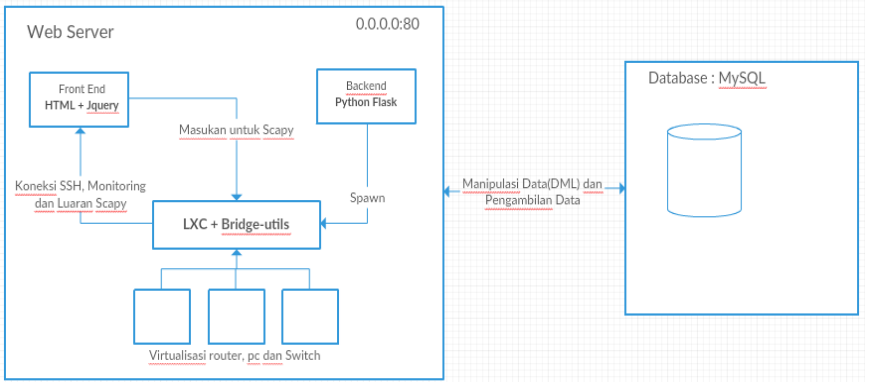

Gambar 2. Desain Arsitektur Sistem

fitur sistem dibagi menjadi dua yaitu fitur untuk praktikan dan fitur untuk admin. Fitur yang tersedia untuk praktikan :

- Praktikan dapat menyalin template virtualisasi yang dibuat oleh admin.

- Praktikan dapat menghidupkan virtualisasi yang telah dibuat.

- Praktikan dapat mematikan virtualisasi yang telah dibuat.

- Praktikan dapat menghapus virtualisasi yang telah dibuat.

- Praktikan dapat mengakses virtualisasi yang telah dibuat menggunakan SSH.

- Praktikan dapat mengatur jaringan virtualisasi.

- Praktikan dapat mengubah konfigurasi jaringan virtualisasi yang sudah diatur sebelumnya.

- Praktikan dapat membuat simulasi paket dengan Scapy. Sedangkan fitur yang tersedia untuk admin:

- Admin dapat membuat template virtualisasi yang nantinya akan digunakan praktikan.

- Admin dapat menambahkan praktikan baru.

- Admin dapat menghapus praktikan.

- Admin dapat menginstal aplikasi pada template sesuai komponen.

- Admin dapat menghapus template virtualisasi yang telah dibuat.

- Admin dapat merubah pengaturan jaringan pada Linux Container.

- Admin dapat memilih template yang digunakan dalam simulasi.

\section{B. Arsitektur Sistem}

Gambar 2 merupakan desain arsitektur dari sistem yang akan dibuat. Sistem dibangun dealam beberapa komponen umum yang terkait satu sama lain, yaitu:

- Backend sebagai pengendali yang menghubungkan basis data dengan frontend.

- Frontend adalah antarmuka dari sistem yang berbasis web.

- Linux Container dan Bridge-utils sebagai lingkungan virtual yang dipanggil dengan bantuan Backend. Digunakan sebagai lingkungan untuk menyimulasikan perangkat jaringan seperti router, switch, komputer dan cloud.

- Basis data sebagai tempat menyimpan segala macam data transaksi maupun data utama sistem.

- Manipulasi paket dengan Scapy sebagai aplikasi yang dapat memodifikasi paket untuk simulasi pengiriman paket oleh praktikan.

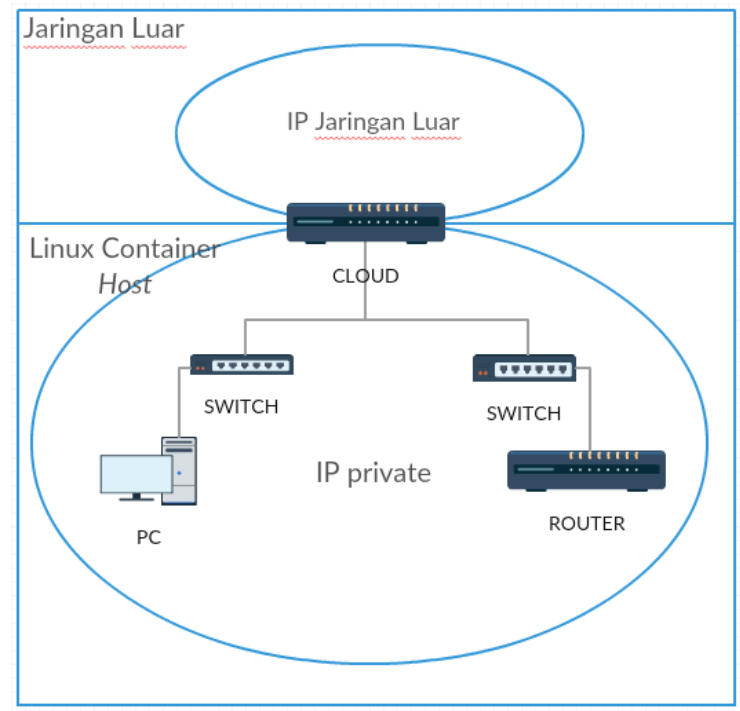

Gambar 1. Desain Komponen Virtualisasi

\section{Desain Backend dan Frontend}

Backend dibuat dengan kerangka kerja dari bahasa python yaitu Flask. Backend akan menangani segala bentuk operasi basis data yang dikirimkan dari frontend, memberikan data yang dibutuhkan frontend, dan mengirim perintah ke Linux Container sesuai dengan data dari frontend. Terdapat tiga jenis rute yang ditangani oleh Backend, yaitu rute yang diakses tanpa autentikasi, rute yang hanya bisa diakses admin, dan rute yang hanya bisa diakses praktikan. Sedangkan bagian frontend menggunakan HTML dan JQuery sedang untuk tampilan simulasi menggunaka pustaka javascript GoJS.

\section{Desain Linux Container dan Bridge-utils}

Linux Container digunakan sebagai lingkungan virtualisasi. Komponen yang divirtualisasikan adalah router, komputer(PC), dan cloud. Admin akan membuat template untuk masing-masing komponen. Sedangkan ketika melakukan simulasi, praktikan akan melakukan penyalinan dari template komponen yang sudah disediakan. Sistem operasi untuk komponen - komponen tersebut adalah Ubuntu.

Komponen cloud digunakan untuk menghubungkan jaringan dalam lingkungan Linux Container dengan jaringan luar menggunakan virtual switch. Bridge-utils digunakan untuk virtual switch tersebut. Selain itu, Bridge-utils juga digunakan untuk menghubungkan komponen-komponen lain yaitu komputer dan router. Dalam komponen cloud diinstal aplikasi shellinabox, aplikasi yang dapat menampilkan terminal melalui peramban, untuk mengakses virtualisasi lain menggunakan koneksi SSH. Untuk melakukan simulasi Scapy, diinstal aplikasi Scapy di dalam komponen komputer.

Komponen komputer dan router dalam lingkungan Linux Container menggunakan alamat IP private sedangkan komponen cloud menggunakan IP yang terhubung dari jaringan luar dan IP private yang terhubung dengan jaringan di lingkungan Linux Container. Gambar 1 merupakan desain dari komponen virtualisasi yang akan diimplementasikan pada sistem. 


\section{E. Desain Manipulasi Paket dengan Scapy}

Scapy adalah program untuk memanipulasi sebuah paket. Praktikan akan mendifinisikan paket terlebih dahulu melalui antarmuka web, kemudian sistem akan membuat sebuah file berekstensi .py yang berisi paket tersebut di dalam komponen virtual komputer. Praktikan dapat menyimulasikan pengiriman paket dengan Scapy melalui komponen virtual computer.

\section{PENGUJIAN DAN EVALUASI}

\section{A. Uji Fungsionalitas}

Uji dilakukan dengan melakukan uji coba membuka aplikasi melalui peramban web. Gambar 3 merupakan desain arsitektur uji fungsionalitas. Uji coba ini berguna untuk menguji apakah operasi-operasi dasar yang dilakukan dapat memberikan hasil yang diharapkan. Peramban web yang digunakan adalah Mozilla Firefox dan fitur add-ons Firebug untuk melihat waktu respon yang diberikan. Tabel 4 merupakan waktu respon ratarata uji fungsionalitas dalam lima kali percobaan.

Tabel 4. Waktu Respon Uji Fungsionalitas

\begin{tabular}{|c|c|c|c|c|c|c|c|}
\hline \multirow[t]{2}{*}{ No } & \multirow{2}{*}{$\begin{array}{l}\text { Nama } \\
\text { Kegiatan }\end{array}$} & \multicolumn{6}{|c|}{ Waktu Respon(ms) } \\
\hline & & 1 & 2 & 3 & 4 & 5 & $\begin{array}{l}\text { Rata- } \\
\text { rata }\end{array}$ \\
\hline 1 & $\begin{array}{l}\text { Login sebagai } \\
\text { admin }\end{array}$ & 765 & 881 & 788 & $\begin{array}{l}120 \\
0\end{array}$ & 840 & 894.8 \\
\hline 2 & $\begin{array}{l}\text { Login sebagai } \\
\text { praktikan }\end{array}$ & 850 & 774 & 853 & 807 & 865 & 829.8 \\
\hline 3 & $\begin{array}{l}\text { Menyalin } \\
\text { template } \\
\text { virtualisasi }\end{array}$ & $\begin{array}{l}993 \\
0\end{array}$ & $\begin{array}{l}217 \\
0\end{array}$ & $\begin{array}{l}193 \\
0\end{array}$ & $\begin{array}{l}337 \\
0\end{array}$ & $\begin{array}{l}725 \\
0\end{array}$ & 4930 \\
\hline 4 & $\begin{array}{l}\text { Menghidupkan } \\
\text { virtualisasi }\end{array}$ & $\begin{array}{l}129 \\
0 \\
\end{array}$ & 370 & 416 & 440 & 526 & 608.4 \\
\hline 5 & $\begin{array}{l}\text { Mematikan } \\
\text { virtualisasi }\end{array}$ & 952 & 857 & 801 & 782 & 714 & 821.2 \\
\hline 6 & $\begin{array}{l}\text { Menghapus } \\
\text { virtualisasi }\end{array}$ & 554 & 433 & 416 & 402 & 378 & 436.6 \\
\hline 7 & $\begin{array}{l}\text { Mengakses } \\
\text { virtualisasi } \\
\text { dengan SSH }\end{array}$ & 80 & 83 & 86 & 76 & 74 & 79.8 \\
\hline 8 & $\begin{array}{l}\text { Mengatur } \\
\text { jaringan } \\
\text { virtualisasi }\end{array}$ & 49 & 56 & 36 & 53 & 48 & 48.4 \\
\hline 9 & $\begin{array}{l}\text { Mengubah } \\
\text { konfigurasi } \\
\text { jaringan } \\
\text { virtualisasi }\end{array}$ & 49 & 8 & 9 & 13 & 56 & 27 \\
\hline 10 & $\begin{array}{l}\text { Membuat } \\
\text { simulasi paket } \\
\text { ICMP dengan } \\
\text { Scapy }\end{array}$ & 45 & 43 & 44 & 50 & 53 & 47 \\
\hline 11 & $\begin{array}{l}\text { Membuat } \\
\text { simulasi paket } \\
\text { TCP dengan } \\
\text { Scapy }\end{array}$ & 50 & 47 & 45 & 42 & 49 & 46.6 \\
\hline 12 & $\begin{array}{l}\text { Membuat } \\
\text { template } \\
\text { virtualisasi }\end{array}$ & $\begin{array}{l}383 \\
0\end{array}$ & $\begin{array}{l}406 \\
0\end{array}$ & $\begin{array}{l}738 \\
0\end{array}$ & $\begin{array}{l}772 \\
0\end{array}$ & $\begin{array}{l}435 \\
0\end{array}$ & 5468 \\
\hline 13 & $\begin{array}{l}\text { Menambahkan } \\
\text { praktikan }\end{array}$ & 69 & 67 & 61 & 74 & 79 & 70 \\
\hline 14 & $\begin{array}{l}\text { Menghapus } \\
\text { praktikan }\end{array}$ & 51 & 55 & 52 & 52 & 54 & 52.8 \\
\hline 15 & Menginstal & 598 & 646 & 519 & 394 & 386 & 5086 \\
\hline
\end{tabular}

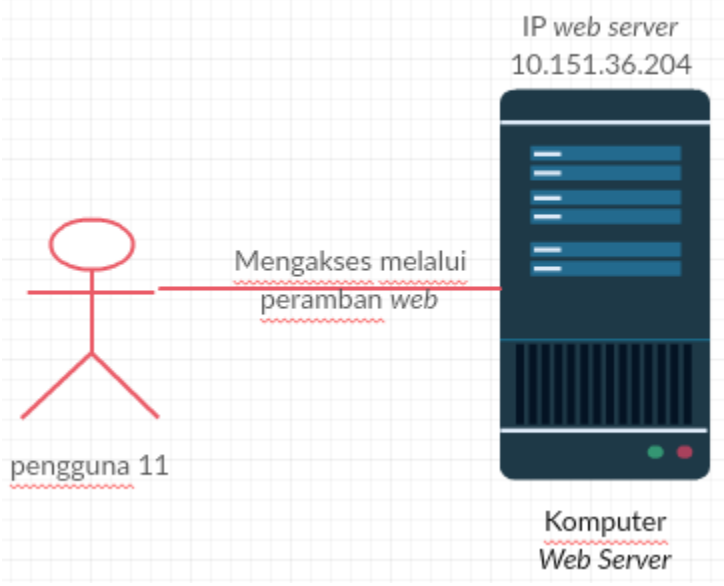

Gambar 3. Desain Arsitektur Uji Fungsionalitas

\begin{tabular}{lllllllll}
\hline No & $\begin{array}{l}\text { Nama } \\
\text { Kegiatan }\end{array}$ & \multicolumn{6}{c}{ Waktu Respon(ms) } \\
\cline { 2 - 8 } & $\mathbf{1}$ & $\mathbf{2}$ & $\mathbf{3}$ & $\mathbf{4}$ & $\mathbf{5}$ & $\begin{array}{c}\text { Rata- } \\
\text { rata }\end{array}$ \\
\hline & $\begin{array}{l}\text { aplikasi pada } \\
\text { template } \\
\text { virtualisasi }\end{array}$ & 0 & 0 & 0 & 0 & 0 & \\
\hline 16 & $\begin{array}{l}\text { Menghapus } \\
\text { template } \\
\text { virtualisasi }\end{array}$ & 458 & 414 & 392 & 375 & 359 & 399.6 \\
\hline 17 & $\begin{array}{l}\text { Mengubah } \\
\text { pengaturan } \\
\text { jaringan Linux } \\
\text { Container }\end{array}$ & 118 & 99 & 111 & 116 & 113 & 111.4 \\
\hline 18 & $\begin{array}{l}\text { Memilih } \\
\text { template untuk } \\
\text { simulasi }\end{array}$ & 123 & 99 & 112 & 132 & 112 & 115.6 \\
\hline
\end{tabular}

\section{B. Uji Fungsionalitas dengan Skenario Modul Praktikum}

Uji dilakukan oleh pengguna dari mahasiswa Teknik Informatika ITS dengan melakukan uji coba sesuai dengan modul praktikum jaringan komputer. Modul yang akan digunakan sebagai uji coba adalah modul web server. Modul tersebut membutuhkan sebuah komponen cloud, sebuah komponen komputer dan sebuah komponen switch.

Web server akan diinstal pada komponen cloud dan aplikasi peramban pada terminal yaitu lynx sudah terinstal pada komputer. Web server akan diakses melalui jaringan ajk dan jaringan dalam Linux Container. Ketika berhasil diakses maka modul web server berhasil dilaksanakan.

Pengujian menggunakan skenario modul praktikum jaringan komputer dilakukan oleh pengguna bernama Daniel Fablius dan Kharisma Nur Annisa. Tabel 5 merupakan hasil pengujian dengan skenario modul praktikum web server.

\section{Uji Kapasistas dan Performa}

Uji kapasitas dan performa terdiri dari dua pengujian, yaitu uji kapasistas dan performa pada komputer web server dan uji

Tabel 5. Hasil Uji Fungsionalitas dengan Skenario Modul Praktikum

\begin{tabular}{lllll}
\hline No & $\begin{array}{l}\text { Nama } \\
\text { Pengguna }\end{array}$ & NRP & Kegiatan & $\begin{array}{l}\text { Keterangan } \\
\text { dan } \\
\text { Catatan }\end{array}$ \\
\hline 1 & $\begin{array}{l}\text { Daniel } \\
\text { Fablius }\end{array}$ & 5113100109 & $\begin{array}{l}\text { Menyalin } \\
\text { komponen } \text { cloud, },\end{array}$ & Berhasil \\
\hline
\end{tabular}




\begin{tabular}{|c|c|c|c|c|}
\hline No & $\begin{array}{l}\text { Nama } \\
\text { Pengguna }\end{array}$ & NRP & Kegiatan & $\begin{array}{l}\text { Keterangan } \\
\text { dan } \\
\text { Catatan }\end{array}$ \\
\hline & & & $\begin{array}{l}\text { switch, dan } \\
\text { komputer. }\end{array}$ & \\
\hline & & & $\begin{array}{l}\text { Mengatur jaringan } \\
\text { sesuai dengan } \\
\text { modul. }\end{array}$ & Berhasil \\
\hline & & & $\begin{array}{l}\text { Melakukan ping } \\
\text { dari cloud ke } \\
\text { komputer. }\end{array}$ & Berhasil \\
\hline & & & $\begin{array}{l}\text { Menginstal aplikasi } \\
\text { apache } 2 \text { dan php5 } \\
\text { pada komponen } \\
\text { cloud. }\end{array}$ & Berhasil \\
\hline & & & $\begin{array}{l}\text { Mengakses } \text { cloud } \\
\text { melalui komputer } \\
\text { Lab AJK dengan } \\
\text { peramban web. }\end{array}$ & Berhasil \\
\hline & & & $\begin{array}{l}\text { Mengakses cloud } \\
\text { melalui komponen } \\
\text { komputer } \\
\text { menggunakan } \\
\text { peramban web lynx }\end{array}$ & Berhasil \\
\hline \multicolumn{5}{|c|}{$\begin{array}{l}\text { Catatan dari pengguna : Perlu ditambahkan cara penggunaan pada halaman } \\
\text { simulasi }\end{array}$} \\
\hline \multirow[t]{6}{*}{2} & $\begin{array}{l}\text { Kharisma } \\
\text { Nur Annisa }\end{array}$ & 5113100026 & $\begin{array}{l}\text { Menyalin } \\
\text { komponen cloud, } \\
\text { switch, dan } \\
\text { komputer. }\end{array}$ & Berhasil \\
\hline & & & $\begin{array}{l}\text { Mengatur jaringan } \\
\text { sesuai dengan } \\
\text { modul. }\end{array}$ & Berhasil \\
\hline & & & $\begin{array}{l}\text { Melakukan ping } \\
\text { dari cloud ke } \\
\text { komputer. }\end{array}$ & Berhasil \\
\hline & & & $\begin{array}{l}\text { Menginstal aplikasi } \\
\text { apache } 2 \text { dan php5 } \\
\text { pada komponen } \\
\text { cloud. }\end{array}$ & Berhasil \\
\hline & & & $\begin{array}{l}\text { Mengakses cloud } \\
\text { melalui komputer } \\
\text { Lab AJK dengan } \\
\text { peramban web. }\end{array}$ & Berhasil \\
\hline & & & $\begin{array}{l}\text { Mengakses cloud } \\
\text { melalui komponen } \\
\text { komputer } \\
\text { menggunakan } \\
\text { peramban web } \\
\text { lynx. }\end{array}$ & Berhasil \\
\hline
\end{tabular}

Catatan dari pengguna : tampilan koneksi dikelompokkan sesuai dengan komponen masing-masing.

kapasitas pada komputer pembanding. Uji coba pada komputer web server dilakukan untuk menguji kemampuan web server dalam menangani simulasi ketika banyak virtualisasi berjalan pada komputer web server.

Uji coba pada komputer pembanding dilakukan untuk mengetahui spesifikasi minimum komputer untuk melakukan virtualisasi menggunakan Linux Container dan seberapa banyak virtualisasi yang dapat dibuat.

Uji kapasitas dan performa dilakukan dengan mengakses web server melalui peramban web pada komputer klien sebanyak sepuluh. Peramban web yang digunakan dimasingmasing komputer adalah Mozilla Firefox dan Chrome. Gambar 4 merupakan desain arsitektur uji coba kapasitas dan performa untuk komputer web server. Berikut langkah - langkahnya dalam proses pengujian dengan komputer web server:

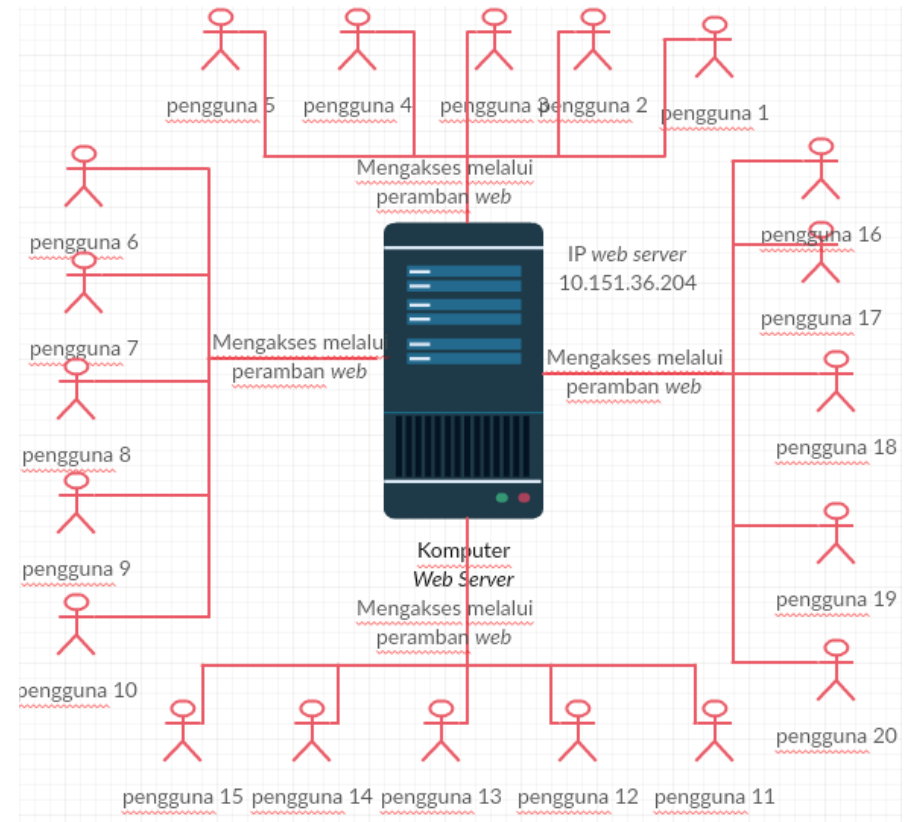

Gambar 4. Desain Arsitektur Uji Kapasitas dan Performa Komputer Web Server

1. Setiap komputer melakukan login dengan dua akun praktikan berbeda, satu akun pada peramban Mozilla dan akun lain pada Chrome. Sehingga jumlah akun pengguna yang digunakan sebanyak 20 akun.

2. Masing - masing akun membuat sebanyak 25 virtualisasi, namun dilakukan secara bertahap yaitu, lima virtualisasi setiap tahapan.

3. Masing - masing tahap dicatat berapa persentase memori RAM yang digunakan dan persentase penggunaan prosesor dengan melihat hasil monitoring dari aplikasi htop serta waktu respon aplikasi ketika menghidupkan virtualisasi terakhir dari masing-masing tahapan. Pencatatan memori RAM dan prosesor dilakukan untuk mengetahui apakah virtualisasi dapat berjalan semestinya dan dapat diakses ketika melakukan simulasi.

Sedangkan uji coba pada komputer pembanding berikut langkah - langkah dalam proses pengujian:

1. Skrip terdiri dari beberapa fungsi, yaitu membuat salinan dari virtualisasi yang sudah ada dan menghidupkan virtualisasi.

2. Fungsi yang dijalankan pertama kali adalah membuat salinanvirtualisasi secara bertahap yaitu 10, 50, 100, 150, 200, dan 250 virtualisasi.

3. Kemudian setelah tahapan penyalinan selesai, fungsi kedua dijalankan dengan bertahap sama seperti langkah yang kedua.

4. Masing- masing tahap dicatat berapa memori RAM yang digunakan dan persentase dari prosesor yang digunakan dengan melihat hasil monitoring dari aplikasi htop.

Tabel 6 menampilkan hasil uji coba kapasitas dan performa pada komputer web server. Waktu respon yang ditampilkan merupakan hasil pencatatan waktu respon aplikasi ketika menghidupkan virtualisasi terakhir dari masing-masing tahapan. 
Tabel 7 merupakan hasil uji kapasitas dan performa pada komputer pembanding. Virtualisasi maksimal yang berhasil dibuat adalah 150 dan 100 dalam kondisi hidup.

Tabel 6. Hasil Hasil Uji Kapasitas dan Performa pada Komputer Web Server

\begin{tabular}{|c|c|c|c|c|}
\hline No & $\begin{array}{l}\text { Jumlah } \\
\text { Virtua- } \\
\text { lisasi }\end{array}$ & $\begin{array}{l}\text { Memori } \\
\text { yang } \\
\text { terpakai } \\
(8 \text { GB })\end{array}$ & $\begin{array}{l}\text { Prosesor yang } \\
\text { terpakai }(4 \text { core })\end{array}$ & $\begin{array}{l}\text { Waktu respon } \\
\text { menghidupkan } \\
\text { virtualisasi } \\
(\mathrm{ms})\end{array}$ \\
\hline 1 & 100 & $22,48 \%$ & $\begin{array}{l}\text { Core } 1: 8,2 \% \\
\text { Core } 2: 13,4 \% \\
\text { Core } 3: 12,2 \% \\
\text { Core } 4: 11,5 \%\end{array}$ & 826 \\
\hline 2 & 200 & $36,83 \%$ & $\begin{array}{l}\text { Core } 1: 22,8 \% \\
\text { Core } 2: 21,2 \% \\
\text { Core } 3: 23,2 \% \\
\text { Core } 4: 23,4 \%\end{array}$ & 1020 \\
\hline 3 & 300 & $45,80 \%$ & $\begin{array}{l}\text { Core } 1: 46,2 \% \\
\text { Core } 2: 44,0 \% \\
\text { Core } 3: 44,6 \% \\
\text { Core } 4: 50,8 \%\end{array}$ & 7510 \\
\hline 4 & 400 & $55,13 \%$ & $\begin{array}{l}\text { Core } 1: 51,7 \% \\
\text { Core } 2: 50,8 \% \\
\text { Core } 3: 50,5 \% \\
\text { Core } 4: 50,2 \%\end{array}$ & 12060 \\
\hline 5 & 485 & $84,50 \%$ & $\begin{array}{l}\text { Core } 1: 12,8 \% \\
\text { Core } 2: 11,9 \% \\
\text { Core } 3: 9,5 \% \\
\text { Core } 4: 13,2 \%\end{array}$ & - \\
\hline
\end{tabular}

Tabel 7. Hasil Hasil Uji Kapasitas dan Performa pada Komputer Pembanding

\begin{tabular}{llll}
\hline No & $\begin{array}{l}\text { Jumlah } \\
\text { Virtualisasi }\end{array}$ & $\begin{array}{l}\text { Memori yang } \\
\text { terpakai(2 GB) }\end{array}$ & $\begin{array}{l}\text { Prosesor yang } \\
\text { terpakai(2 core })\end{array}$ \\
\hline 1 & 10 & $9,6 \%$ & $\begin{array}{l}\text { Core } 1: 0.0 \% \\
\text { Core } 2: 0.7 \%\end{array}$ \\
\hline 2 & 50 & $37,4 \%$ & $\begin{array}{l}\text { Core } 1: 3.2 \% \\
\text { Core } 2: 0.0 \%\end{array}$ \\
\hline 3 & 100 & $47,7 \%$ & $\begin{array}{l}\text { Core } 1: 0.0 \% \\
\text { Core } 2: 5.1 \%\end{array}$ \\
\hline 4 & 150 & $61,6 \%$ & Core $1: 12.3 \%$ \\
& & & Core $2: 3.7 \%$ \\
\hline
\end{tabular}

\section{Evaluasi}

Berdasarkan hasil uji fungsionalitas, sistem dapat berjalan. Rata-rata waktu yang dibutuhkan untuk mengakses sekitar lima detik. Sedangkan berdasarkan hasil uji kapasitas dan performa, komputer web server dapat menangani virtualisasi sebanyak 400 ketika web server sedang digunakan oleh 20 pengguna dengan persentase memori RAM sebesar 55, 13\%, prosesor rata-rata $50 \%$ dan waktu respon ketika menghidupkan virtualisasi mencapai sekitar 12 detik.

Modul praktikum jaringan komputer berupa web server sudah berhasil dilakukan oleh pengguna bernama Daniel Fablius dan Kharisma Nur Annisa menggunakan aplikasi simulasi jaringan ini.

Sedangkan minimal spesifikasi komputer yang dapat digunakan untuk menjalankan sistem adalah komputer dengan prosesor dual core dan memori RAM sebesar 2 GB. Dengan jumlah maksimal virtualisasi yang dapat dibuat sejumlah 100 virtualisasi, karena pada pengujian sebanyak 150 virtualisasi, komputer tidak dapat diakses lagi.

\section{KESIMPULAN}

Dalam proses pengerjaan Tugas Akhir yang melalui tahap perancangan, implementasi, serta uji coba, didapatkan kesimpulan sebagai berikut :

1. Aplikasi simulasi jaringan menggunakan Linux Container dan manipulasi paket menggunakan Scapy untuk praktikum jaringan komputer dapat diimplementasikan dengan waktu respon kepada pengguna rata -rata sekitar lima detik.

2. Komputer web server dapat menangani virtualisasi sebanyak 400 ketika web server sedang digunakan oleh 20 pengguna dengan persentase memori RAM sebesar 55, $13 \%$, prosesor rata-rata $50 \%$ dan waktu respon ketika menghidupkan virtualisasi mencapai sekitar 12 detik.

3. Spesifikasi komputer yang dapat digunakan untuk menjalankan sistem adalah komputer dengan prosesor dual core dan memori RAM sebesar 2 GB. Dengan maksimal virtualisasi sebanyak 100 dengan persentase persentase yang digunakan RAM $47,7 \%$ dan prosesor $5,1 \%$.

\section{DAFTAR PUSTAKA}

[1] M. J. Scheepers, "Virtualization and Containerization of Application Infrastructure: A Comparison," University of Twente, Enschede, 2014.

[2] Scapy, "secdev," secdev.org, [Online]. Available: http://www.secdev.org/projects/scapy/. [Accessed 6 April 2015].

[3] J. Pan, "A Survey of Network Simulation Tools: Current Status and Future Developments," http://www.cse.wustl.edu/, Saint Louis, 2008.

[4] linuxcontainers.org, "linuxcontainers.org," linuxcontainers.org, [Online]. Available: https://linuxcontainers.org/lxc/introduction/. [Accessed 6 April 2015].

[5] sourceforge.net, "sourceforge.net," sourceforge.net, [Online]. Available: http://lxc.sourceforge.net/man/lxc.html. [Accessed 6 April 2015].

[6] pocoo.org, "flask.pocoo.org," pocoo.org, [Online]. Available: http://flask.pocoo.org/. [Accessed 15 Oktober 2015].

[7] Northwoods Software, "gojs.ne," Northwoods Software, [Online]. Available: http://gojs.net/latest/index.html. [Accessed 20 Oktober 2015].

[8] linuxfoundation.org, "linuxfoundation.org," linuxfoundation.org, November 2009. [Online]. Available: http://www.linuxfoundation.org/collaborate/workgroups/networking/bridge. [Accessed 6 April 2015]. 